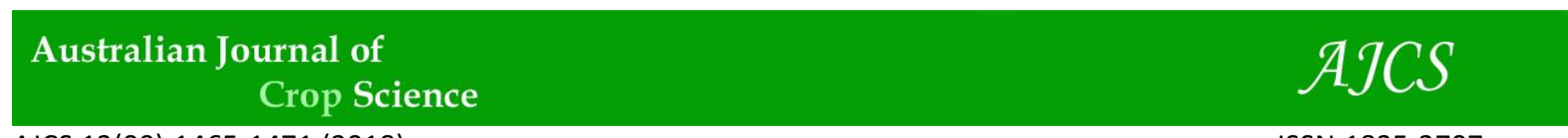

AJCS 12(09):1465-1471 (2018)

ISSN:1835-2707

doi: 10.21475/ajcs.18.12.09.PNE1142

\title{
Morphological development and yield of wheat irrigated under nitrogen and potassium fertilization in Cerrado Oxisol
}

\section{Edna Maria Bonfim-Silva ${ }^{1}$, Danityelle Chaves de Freitas ${ }^{1}$, Tonny José Araújo da Silva ${ }^{1}$, William Fenner ${ }^{2}$, Helon Hébano de Freitas Sousa ${ }^{1}$}

\author{
${ }^{1}$ Federal University of Mato Grosso - UFMT, Institute of Agricultural and Technological Sciences - ICAT, 5055 \\ Students Avenue Rondonópolis, 78.735-901, Brazil \\ ${ }^{2}$ Federal University of Mato Grosso - UFMT, Faculty of Agronomy and Zootechnic - FAAZ, 2367, Fernando Corrêa da \\ Costa Avenue, 78060-900, Cuiabá, Brazil
}

\begin{abstract}
This study aimed at assessing the effects of nitrogen-potassium interaction on dry matter and grain yield of irrigated wheat (Triticum aestivum L.) grown in the Brazilian Cerrado. The experiment was conducted for two consecutive cropping seasons (2014 and 2015), between March and August. The experiment was arranged in a randomized block design. Treatments consisted of five nitrogen and five potassium doses in a factorial scheme $(5 \times 5)$. The analyzed variables consisted of the shoot and spike dry weights, and grain yield. In both years (2014 and 2015), isolated effects of nitrogen and potassium doses were observed on the assessed traits. In 2014, the highest results were achieved by the respective nitrogen and potassium doses: 145.02 and $148.32 \mathrm{~kg}^{-1} \mathrm{for}$ shoot dry weight, 133.79 and $139.85 \mathrm{~kg} \mathrm{ha}^{-1}$ for spikes, and 119.14 and $138.83 \mathrm{~kg} \mathrm{ha}^{-1}$ for grain yield. Yet in 2015, no significant results were identified, while nitrogen doses showed a linear effect on shoot and spike dry weights, potassium rates revealed such effect on grain yield. Although nitrogen showed a higher response in terms of dry weight for shoot and spikes, potassium induced the largest increases in productivity. Thus, for greater efficiency of fertilization, a careful analysis of the level of soil fertility, the expected productivity and the technological level employed is necessary. It should be emphasized that the management of fertilization has specificities every year, requiring constant adaptation.
\end{abstract}

Keywords: BRS 254 wheat; Cerrado wheat production; nitrogen-potassium ratio; nitrogen and potassium fertilizations; Triticum aestivum.

Abbreviations: ANOVA_variance analysis; CAPES_coordination for improvement of higher education personnel; CEC_cation exchange capacity; CNPq_national council for scientific and technological development; EMBRAPA_brazilian agricultural research company; $\mathrm{ET}_{\text {o_ }}$ reference evapotranspiration; $\mathrm{FAO}_{-}$food and agriculture organization of the united nations; FAPEMAT_research support foundation of the state of mato grosso; FTE_fritted trace elements; KCL_potassium chloride; O.M._organic matter; SAS_statistical analysis software; SB_sum of bases; SDW_shoot dry weight; SpDW_spike dry weight; V_base saturation; WY_wheat yield;

\section{Introduction}

Wheat (Triticum aestivum L.) has been widely accepted as one of the most significant food crops for human consumption. It is grown across extensive areas worldwide, accounting for nearly $30 \%$ of the total global grain output. This versatile plant is adapted to a broad range of environmental conditions and is suitable as an alternative to crop rotation. On a temporal scale, it was first grown in South Brazil, under rainfed field conditions. Recently, this crop has expanded to the Southeast and Central-West regions of the country as an irrigated crop, with an average wheat grain yield of $2,228 \mathrm{~kg} \mathrm{ha}^{-1}$ in 2015 (IBGE, 2016).

Oxisols under Cerrado vegetation (savanna-like environment) are characterized by low natural fertility because of extensive base leaching and high iron and aluminum oxide levels, restricting crop development (Lopes and Guilherme, 2016). Despite this, the Brazilian Cerrado is one of the main producing regions of Brazil and the world.
The temperature is favorable to the cultivation during the full year and the water regime has two well-defined seasons, with rainy summer and dry winter. This environment supports cultivation of up to three harvests per year if irrigation systems are used. However, special attention should be given to crop rotation and nutrient management. Nitrogen ranks first among all the essential nutrients as the most limiting for plant growth, with an increasing demand. It is a vital constituent of the chlorophyll, protein, and nucleic acid molecules (Fernandes, 2006). Despite not taking part in any chemical structure of organic compounds, potassium enhances the resistance to lodging in wheat plants. It has been reported that nitrogen and phosphorus fertilization can be more effective when potassium fertilization increases (Niu et al., 2013). For Chuan et al. (2013), N is the most limiting nutrient for wheat yield, followed by $P$ and $K$. Besides that, potassium increases grain yield if not in excess 
thereof (Zhan et al., 2016). In the soil-plant system, nutrients interact in several ways, whether by chemical precipitations and combinations or by nutrient interaction with the plant cell, which sometimes occurs during absorption, transport, redistribution, and metabolism. The efficiency of fertilization depends on specific conditions such as soil fertility, meteorological conditions, and crop management (Theago et al., 2014). The interaction between nitrogen and potassium reveals some characteristics of soil-plant dynamics. Potassium is known to participate in the activation of nitrogen assimilating enzymes and protein and starch synthesis in leaves (Fernandes, 2006). This dynamic will be affected directly by plant growth, resulting in higher development and production of leaves, spikes and yield grains. Since new wheat cultivars have emerged, the possibility of pushing farming areas towards new boundaries has raised. Furthermore, the goals of this study are the need to understand nutrient interactions in morphological development and yield of wheat crops, mainly nitrogen and potassium in Oxisol under tropical climate. Thus, we aimed to verify the effect of the interaction between these nutrients on dry matter production of irrigated-wheat and grain yield in the Cerrado of Mato Grosso, Brazil.

\section{Results}

\section{Shoot dry weight}

The results of shoot dry weight were fit to a quadratic regression model as a function of both nitrogen (Fig 1a) and potassium (Fig 1b) doses during the crop season of 2014, and to a linear model for nitrogen (Fig 2) in the crop season of 2015. As for productivity, shoot dry weight effects were isolated in 2014. Conversely, nitrogen fertilization solely induced outstanding increases on this variable.

In 2014, the highest shoot dry weight production was achieved by the nitrogen and potassium rates of $145.02 \mathrm{~kg}$ $\mathrm{ha}^{-1}$ and $148.32 \mathrm{~kg} \mathrm{ha}^{-1}$, respectively. Shoot dry weight increments were $43.23 \%$ (from 556.94 to $797.68 \mathrm{~kg} \mathrm{ha}^{-1}$ ) and 49.35 (from 500.93 to $748.15 \mathrm{~kg} \mathrm{ha}^{-1}$ ) for nitrogen and potassium, respectively, (Fig 1a and 1b); whereas in 2015, the rise in shoot dry weight due to nitrogen fertilization reached a $62.38 \%$ increase (from 546.43 to $887.30 \mathrm{~kg} \mathrm{ha}^{-1}$ ) (Fig 2).

\section{Spikes dry weight}

Regarding the wheat spikes, dry weight values were adjusted to a quadratic regression model for nitrogen and potassium separately in 2014 and to a linear model for nitrogen singly in 2015. The highest spike dry weights were observed at the rates of $133.79 \mathrm{~kg} \mathrm{ha}^{-1}$ nitrogen and 139.85 $\mathrm{kg} \mathrm{ha}^{-1}$ of potassium (Fig $3 \mathrm{a}$ and $3 \mathrm{~b}$ ). The increments were $40.69 \%$ for nitrogen and $65.54 \%$ for potassium, from the lowest dose (Fig 4).

\section{Wheat yield}

Wheat yield was fit to a quadratic regression model for nitrogen and potassium doses in 2014 and to a linear model for potassium in 2015. Compared to the absence of nitrogen fertilization, the nitrogen dose of $119.14 \mathrm{~kg} \mathrm{ha}^{-1}$ provided the highest estimated yield (790.99 $\mathrm{kg} \mathrm{ha}^{-1}$ ), standing for an increase of $22.80 \%$ (Fig $5 \mathrm{a}$ ). Yet for potassium, the $138.83 \mathrm{~kg}$ $\mathrm{ha}^{-1}$ dose provided the highest wheat yield (Fig $5 \mathrm{~b}$ ), which was $1120.51 \mathrm{~kg} \mathrm{ha}^{-1}$, i.e. an increase of $77.71 \%$ compared to the lowest dose.

In the second growing year (2015), wheat yield showed a linear fit as a function of potassium doses (Fig 6), increasing by $34.84 \%$ due to the rise in potassium doses if compared to treatments without potassium fertilization.

\section{Discussion}

\section{Overview}

Wheat yield components revealed isolated significance for nitrogen and potassium doses during both crop seasons. Each nutrient effect was isolated for the variables during the crop season of 2014 when crop response to nitrogen and potassium was fit to a quadratic regression model. The nitrogen induced greater production outputs such as shoot and spike dry weight, when compared to potassium.

During 2015 season, potassium fertilization induced a significant rise in productivity, while nitrogen stimulated shoot and spikes dry mass. In the same year, wheat crop responses were adjusted to a linear regression model.

\section{Biomass production}

Given the significant role of nitrogen in plant metabolism, suitable doses substantially improved plant development and; therefore, shoot dry weight rises. The dry mass yield of every plant species is directly related to nutrient absorption, assimilation, and accumulation in vegetative parts, as well as its subsequent translocation to grains, where they are stored as starch and protein (Fig 1a, 1b and 2).

The nitrogen is only assimilated as $\mathrm{NH}_{4}{ }^{+}$, even if absorbed as $\mathrm{NO}_{3}{ }^{-}$and $\mathrm{NH}_{4}^{+}$. Yet, when in excess, $\mathrm{NH}_{4}{ }^{+}$could interfere with the plant water balance, thereby exerting a toxic effect (Fernandes, 2006). Theago et al. (2014) assessed the effect of nitrogen doses, sources, and timing of application on wheat crop yield and chlorophyll content. Importantly, these authors reported that nitrogen efficiency depends on certain conditions, such as cultivar, crop management practice, soil type, and climate.

When applied in a single combined dose, nitrogen and potassium promoted a nutritional imbalance to wheat plants. In addition, plant shoot dry weight had no significant increase with the increasing doses of both nutrients. While assessing nutrient uptake in two wheat cultivars, Gargantini et al. (1973) recorded expressive wheat development from the day 30 after emergence and a cultivar-dependent nutrient absorption. In this perspective, this study highlights a significant effect of nitrogen fertilization on the use of nutrients by wheat, avoiding waste, and enhancing plant development, and finally a high-quality cereal. Assessing the growth and initial development of greenhouse-grown wheat plants under nitrogen fertilization, Pietro-Souza et al. (2013) confirmed such rise in shoot dry weight resulting from nitrogen application. 
Table 1. Mean characterization chemical of 0.00-0.20 m depth prior to the experiments of 2014 and 2015, Rondonópolis - MT, Brazil.

\begin{tabular}{lllllllllllllll}
\hline $\mathrm{pH}$ & $\mathrm{Ca}$ & $\mathrm{Mg}$ & $\mathrm{Al}$ & $\mathrm{CEC}$ & $\mathrm{O} . \mathrm{M}$. & $\mathrm{P}$ & $\mathrm{K}$ & $\mathrm{Zn}$ & $\mathrm{Cu}$ & $\mathrm{Fe}$ & $\mathrm{Mn}$ & $\mathrm{B}$ & $\mathrm{S}$ & $\mathrm{V}$ \\
\hline $\mathrm{CaCl}_{2}$ & $-----\mathrm{Cmol}_{\mathrm{c}} \mathrm{dm}^{-3}----$ & $\mathrm{g} \mathrm{kg}^{-1}$ & ---1 & & & & & & & & & $\%$ \\
2014 & & & & & & & & & & & & \\
4.0 & 0.35 & 0.10 & 1.30 & 7.60 & 18.70 & 3.40 & 52.00 & 0.50 & 0.85 & 122.50 & 19.00 & 0.13 & 6.00 & 8.30 \\
\hline 2015 & & & & & & & & & & & & & & \\
\hline 5.32 & 2.40 & 0.93 & 0.00 & 6.53 & 26.32 & 9.41 & 70.82 & - & - & - & - & - & - & 53.79 \\
\hline
\end{tabular}

Calcium Chloride ( $\mathrm{CaCl}_{2}$ ), Phosphorus (P), Potassium (K), Calcium (Ca), Magnesium (Mg), Hydrogen (H), Aluminum (Al), Sum of Bases (SB), Cation Exchange Capacity (CEC), Base Saturation (V) and Organic Matter (O. M.).
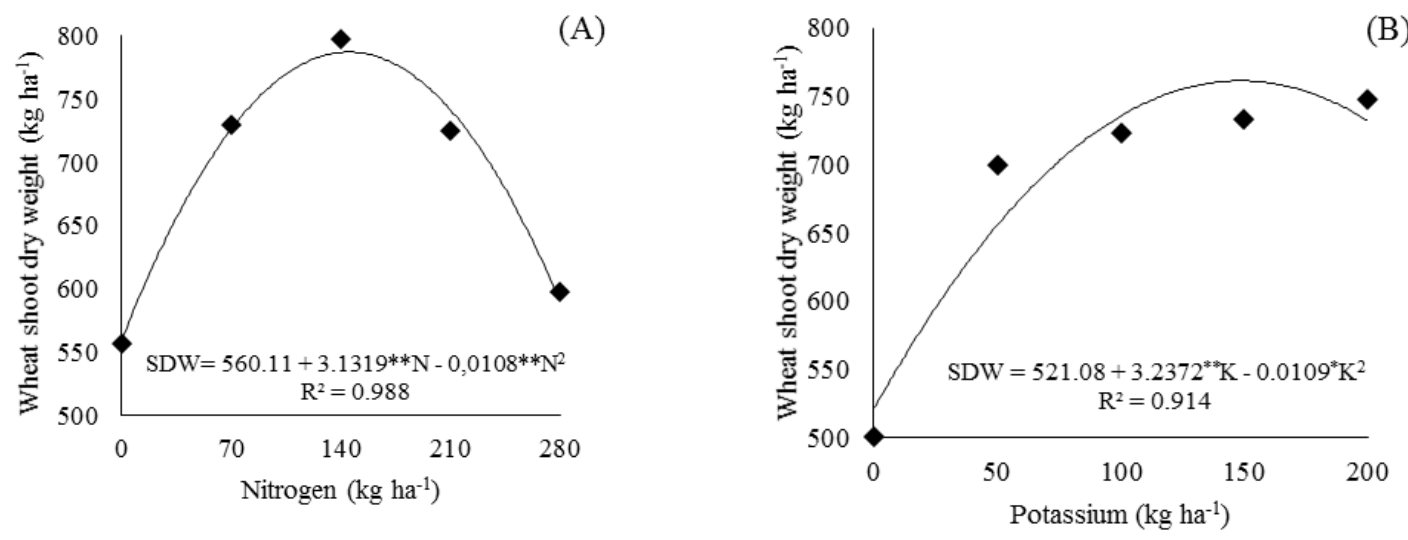

Fig 1. Wheat shoot dry weight in function of nitrogen (A) and potassium (B) doses fertilizations applied in the 2014 crop season, in Rondonópolis - MT, Brazil. ${ }^{* *}, *$ significant at $1 \%$ and at $5 \%$, respectively.

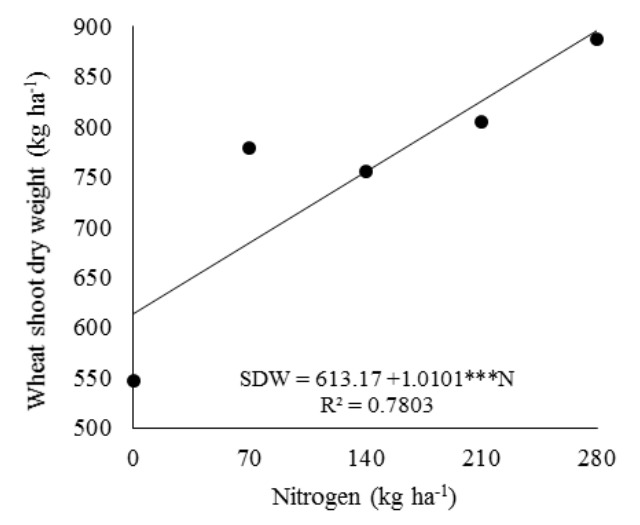

Fig 2. Wheat shoot dry weight in function of nitrogen fertilizations doses applied in the 2015 crop season, in Rondonópolis - MT, Brazil. ***, significant at $0.1 \%$.
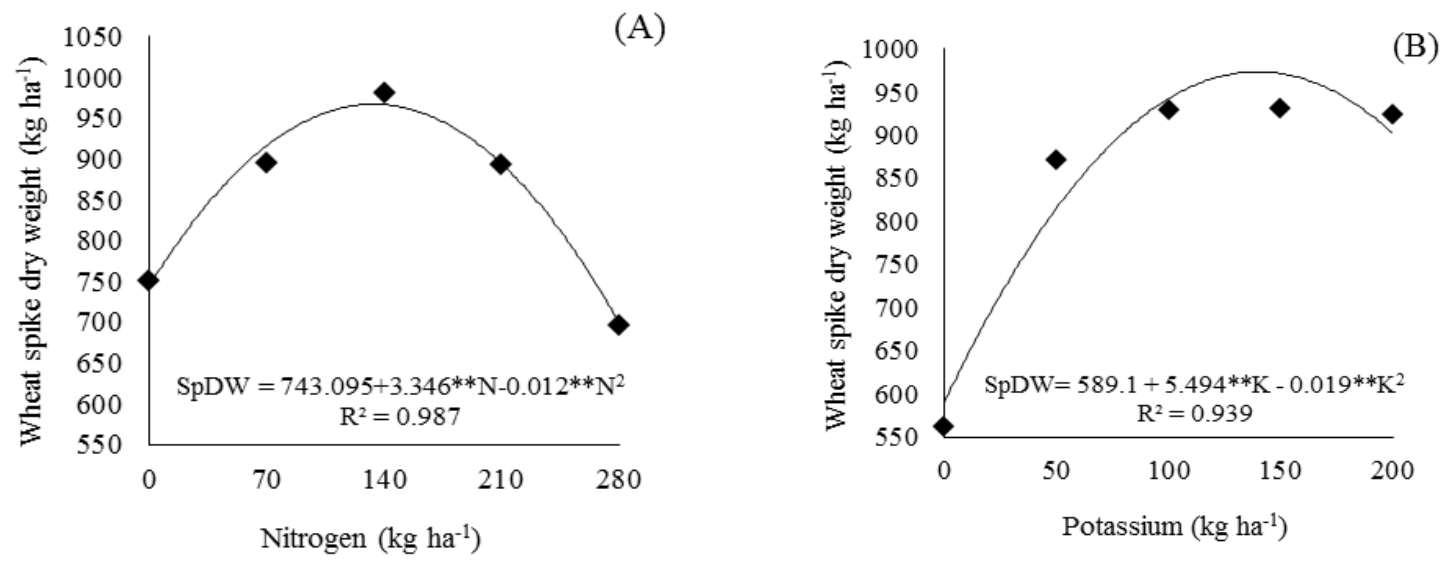

Fig 3. Wheat spike dry weight in function of nitrogen (A) and potassium (B) fertilizations doses in the 2014 crop season, Rondonópolis - MT, Brazil. **, significant at $1 \%$. 


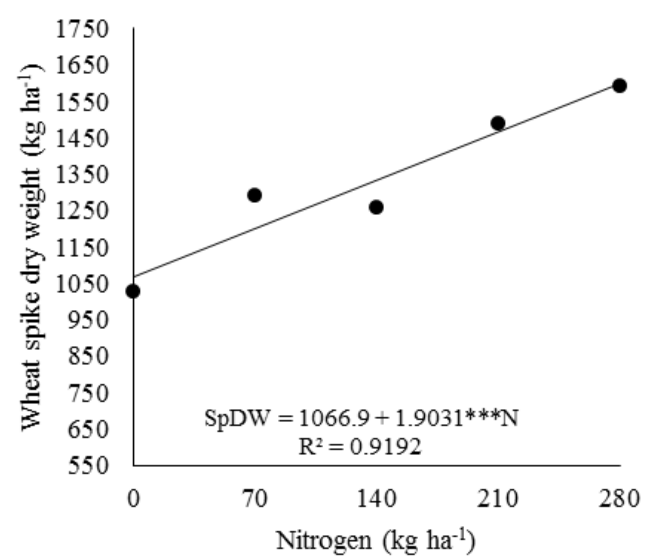

Fig 4. Wheat spike dry weight in function of nitrogen fertilizations doses in the 2015 crop season, Rondonópolis - MT, Brazil. ***, significant at $0.1 \%$.
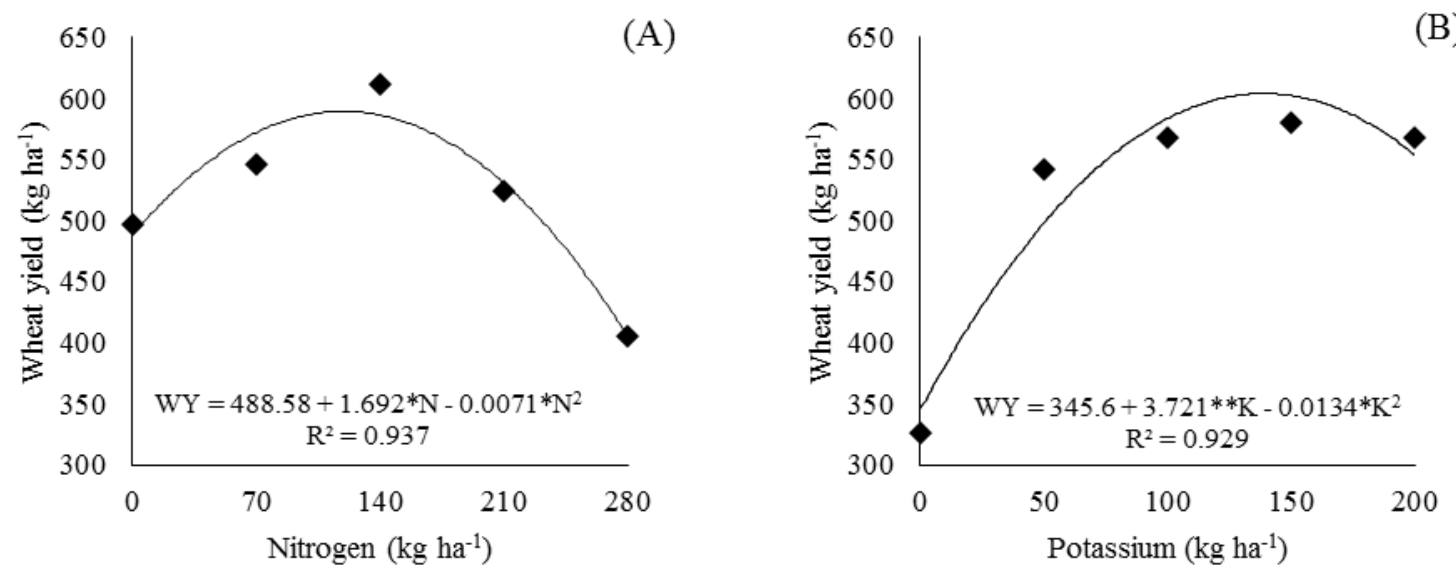

Fig 5. Wheat yield in function of nitrogen (A) and potassium (B) fertilizations doses in the 2014 crop season, Rondonópolis - MT, Brazil. **, * significant at $1 \%$ and $5 \%$, respectively.

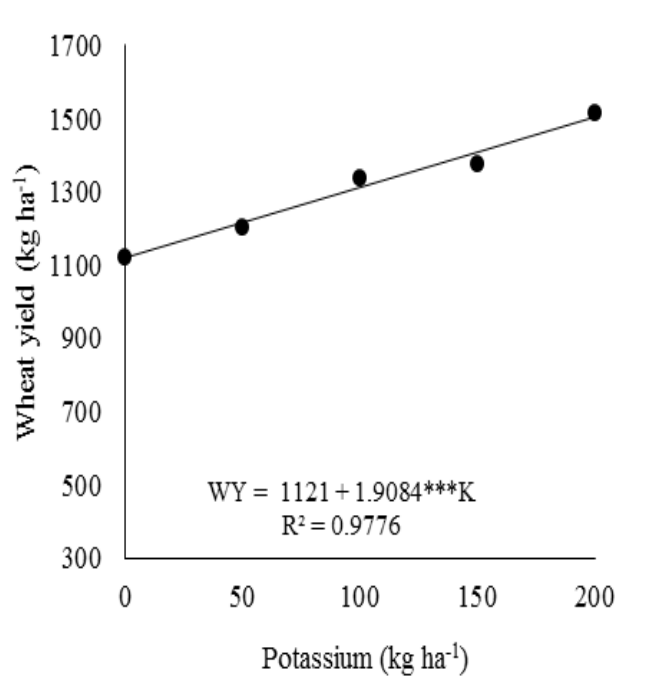

Fig 6. Wheat yield in function of potassium fertilizations doses in the 2015 crop season, Rondonópolis - MT, Brazil. *** significant at $0.1 \%$. 

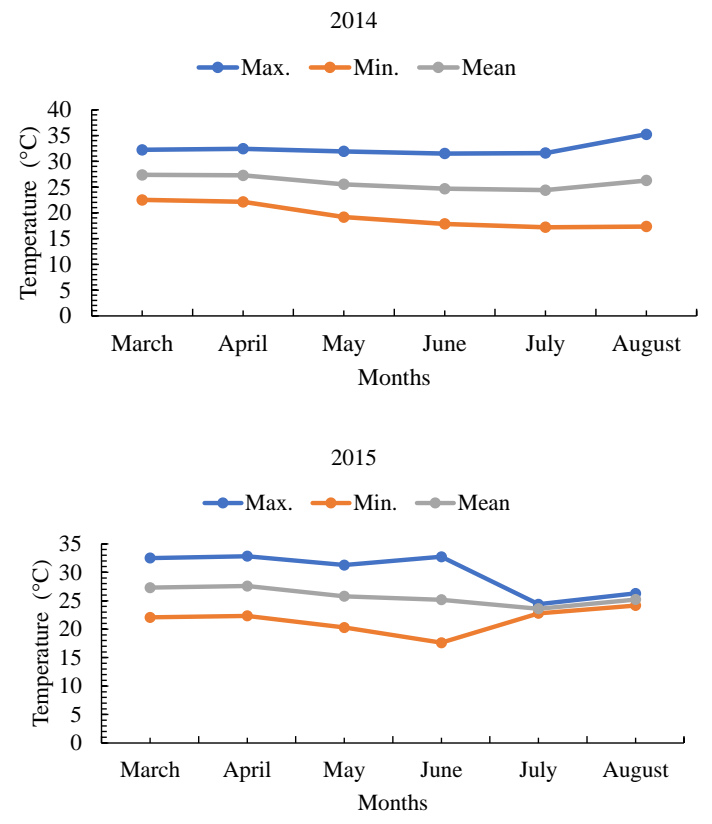

Fig 7. Temperature variation of experimental period for years of 2014 and 2015, Rondonópolis, Mato Grosso State, Brazil.

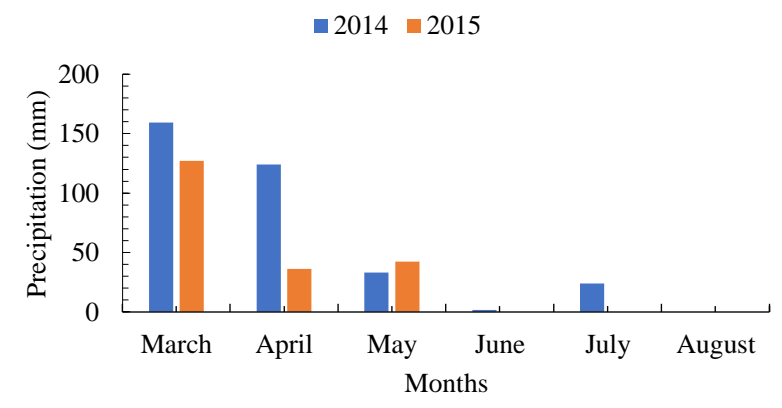

Fig 8. Accumulated precipitation during the experimental period for years of 2014 and 2015, Rondonópolis, Mato Grosso State, Brazil.

\section{Spike development}

After studying the same cultivar (BRS 254) under greenhouse conditions, Carvalho et al. (2016) confirmed that nitrogen and potassium doses affect the behavior of spike dry weight, albeit in an isolated fashion, such as this study (Fig 3a, 3b and 4).

Plant capacity to absorb and use nitrogen is the main advantage deriving from the relationship between nitrogen and potassium (Brar et al., 2011). Nitrogen participates in the synthesis of amino acids and proteins, increasing wheat quality and crop yield. However, for such synergism to occur, wheat plants must be in nutritional balance for the achievement of a maximum yield. On the other hand, potassium absorption happens mainly via mass flow absorption, as $\mathrm{K}^{+}$, and efficiency depends on transpiration and concentration of nutrients within the soil solution. Nevertheless, absorption rates decrease with plant age (Fernandes, 2006).

The wheat tillering stage is fundamental to the growing and differentiation of wheat spikes as well as to wheat plant growth. Bredemeier and Mundstock (2001) tested the effect of applying nitrogen during this stage on the rise in the number of spikes, confirming a positive impact as well. These authors also reported varied responses according to the cultivar selected for the study. Over several years with successive fertilization, nutrient reserves are established through a process known as "building soil fertility" (Rosolem et al., 2012; Lopes and Guilherme, 2016).

\section{Yield grains}

The individual responses of nitrogen and potassium in 2014 and potassium alone in 2015 were likely the result of the soil low natural fertility since this region was newly cultivated and only recently converted into a cropping area (Fig $5 a, 5 b$ and 6). Some conditioning factors for a better absorption and assimilation of nutrients by wheat plants include low cation exchange capacity, environmental conditions during experiment and nitrogen topdressings. Water deficit or 
excess are other predominant features responsible for the leaching or volatilization of potassium and nitrogen (Mendes et al., 2016). Flumignan et al. (2013) verified a 3-fold increase in treatment efficiency of properly water supplied plants, while studying irrigation influence on wheat production.

Zhang et al. (2011) evaluated long-term continuous fertilization results and observed increases in wheat and maize yields in five locations in China. These authors also recorded increases of up to $21 \%$ in wheat grain yield when compared $\mathrm{N}, \mathrm{P}$, and $\mathrm{K}$ fertilizations with $\mathrm{N}$ and $\mathrm{P}$. Recent studies by Duan et al. (2014) showed positive effects of nitrogen use and its long-term association with potassium and phosphorus on wheat and rice crops in China. The same authors alleged reduced loss and increased efficiency of nitrogen use when combined phosphorus and potassium.

Prior to establishing nutrient management strategies, geographic, meteorological, and soil conditions must be taken into consideration (Duan et al., 2014) since they exert a direct influence on crop yield. Singh et al. (2014) studied the optimization of nutrient management techniques in rice and wheat crops in India and highlighted the significance of crop demand, soil nutrient availability, and environmental conditions on these crops' agronomic efficiency.

Hejcman et al. (2012) assessed sustainability in winter wheat production after 50 years of fertilization with nitrogen, phosphorus, and potassium in the Czech Republic. These authors evidenced the importance of crop rotation on yields and soil natural fertility on fertilization management practices, mainly for nitrogen. Likewise, Niu et al. (2013) affirmed that $\mathrm{N}$ and $\mathrm{P}$ absorptions could increase with $\mathrm{K}$ fertilization.

In addition, differences in fertilization timing for both nitrogen and potassium might have played a role in the individual responses of the characteristics assessed. Potassium was applied in a single dose at sowing time, while nitrogen was spread twice, one at sowing $(30 \%)$ and one at top-dressing $(70 \%)$. Moreover, potassium may have been poorly absorbed and at a distinct rate from that of nitrogen to promote increases in the evaluated characteristics (Fernandes, 2006).

Duan et al. (2014) investigated the effect of combining different doses of phosphorus and potassium with nitrogen in wheat and rice in China. These authors conducted 16- and 24-year studies in five localities and highlighted the significance of phosphorus and potassium fertilizations for the improvement of the used nitrogen. They also reported a drop of nearly $21 \%$ in nitrogen losses when applied with potassium if compared to combinations with single phosphorus. Yan et al. (2015) reported that $\mathrm{N}$ fertilizations are strongly correlated with crop growth rate increase and water use efficiency.

Furthermore, Theago et al. (2014) assessed the interaction among doses, sources, and periods of nitrogen application on wheat yield and chlorophyll contents in areas under notillage systems for 25 and 9 years. At the end, they recorded a productivity of $4,598 \mathrm{~kg} \mathrm{ha}^{-1}$, when applied $100 \mathrm{~kg} \mathrm{ha}^{-1}$ nitrogen. Under such conditions, the authors recommended that all the nitrogen contents should be supplied at sowing. Moreover, Alves et al. (2015) studied wheat yield components under different nitrogen top-dressing doses and verified a positive correlation between nitrogen application on the number of spikes and plant productivity, but diminishing grain mass as nitrogen rates increased. For Mojid et al. (2012), doses of nitrogen above the optimal can promote excessive vegetative growth in wheat plants, maximizing the losses of nutrients.

\section{Materials and Methods}

\section{Location and general description}

The experiment was performed in farm plots located in Rondonópolis, State of Mato Grosso (Brazil), which belong to the Federal University of Mato Grosso. The area lies on the geographic coordinates of $16^{\circ} 27^{\prime} 54.98^{\prime \prime} S$ and $54^{\circ} 34^{\prime} 41.75^{\prime \prime}$ $\mathrm{W}$, at an altitude of $287 \mathrm{~m}$. The experiment was done for two consecutive cropping seasons (2014 and 2015), between March and August.

Local soil was classified as an Oxisol $\left(549,84\right.$ and $367 \mathrm{~g} \mathrm{~kg}^{-1}$ of sand, silt and clay, respectively). The cropping has been only recently started, using wheat as the first crop. The soil was chemically analyzed followed by a two-year fallow period for acidity correction and $60 \%$ base saturation (Table 1). The BRS 254 wheat cultivar, developed by EMBRAPA (Brazilian Agricultural Research Company) was used. This cultivar has a 100-day growth cycle on average as irrigated crop for the Cerrado biome (Só e Silva et al., 2008). The temperature (maximum, minimum and mean) and precipitation (accumulated) were registered during the experimental period (Fig 7 and 8).

\section{Experimental design and treatments}

A completely randomized block design in a $5 \times 5$ factorial scheme was adopted, combining five nitrogen doses $(0,70$, 140,210 , and $\left.280 \mathrm{~kg} \mathrm{ha}^{-1}\right)$ and five potassium doses $(0,50$, 100,150 and $200 \mathrm{~kg} \mathrm{ha}^{-1}$ ) with four replications, resulting in 100 experimental plots. Each plot included nine $6-\mathrm{m}$ rows spaced $0.2 \mathrm{~m}$ apart. Seven middle rows were considered as a floor area, eliminating $0.75 \mathrm{~m}$ from each edge $\left(6.3 \mathrm{~m}^{2}\right)$. Seventy seeds were sown per linear meter at a $0.03-\mathrm{m}$ depth, using a no-tillage seeder model SEMINA II. Irrigation was performed by applying a water depth corresponding to the reference evapotranspiration $\left(\mathrm{ET}_{\mathrm{o}}\right)$, which was estimated by the Penman-Monteith-FAO method. An automatic meteorological station, nearby the experiment area, provided the necessary meteorological information for the model. A self-propelled mechanized irrigation system was used to irrigate crops. In the years of 2014 and 2015 total applied (precipitation + irrigation) were 498.15 and 448.22 $\mathrm{mm}$, respectively, during the period of the experiment. Potassium doses were applied at sowing time, using potassium chloride $(\mathrm{KCl})$ as a source. Phosphorus $\left(\mathrm{P}_{2} \mathrm{O}_{5}\right)$ was applied through simple superphosphate at the recommended dose $\left(200 \mathrm{~kg} \mathrm{ha}^{-1}\right)$. Next, nitrogen doses were applied with urea as a source into two doses: one at sowing time $(30 \%)$ and 14 days after wheat emergence - tillering stage $(70 \%)$. The demands for micronutrients were met by applying $30 \mathrm{~kg} \mathrm{ha}^{-1}$ FTE (Fritted Trace Elements) BR12 (9\% Zn - $1.8 \%$ B - $0.8 \% \mathrm{Cu}-2 \% \mathrm{Mn}-3.5 \% \mathrm{Fe}-0.1 \% \mathrm{Mo})$.

\section{Measured variables and statistical analysis}

The variables were assessed at harvest time after physiological maturity when plants were senescing. The 
wheat cycle lasted for a total of 93 and 108 days for the 2014 and 2015 crop seasons, respectively. The entire plot areas were harvested for evaluations of the shoot (leaves and stems), spike, and grain dry weights. The estimates were made after the threshing of spikes and grain humidity correction to $13 \%$, on a wet basis. All the variables were expressed in $\mathrm{kg} \mathrm{ha}^{-1}$.

The results were submitted to variance analysis (ANOVA) at $5 \%$ probability, and when significant, a regression analysis was performed with the help of the software SAS (2002).

\section{Conclusion}

Irrigated wheat responded differently to nitrogen and potassium fertilizations during the crop seasons of 2014 and 2015 in the Brazilian Cerrado. Potassium fertilization promoted a productivity increase when compared with the nitrogen. However, the linear response to potassium did not permit the ideal nutrient doses to be defined for irrigated wheat in this region. The applications of nitrogen elevated shoot and spike dry weights. Again, the best nitrogen dose could not be determined during the second growing season due to the linear effect of wheat responses.

\section{Acknowledgements}

The authors express their gratitude to the following organizations for collaborating in the accomplishment of this study: CAPES (Coordination for Improvement of Higher Education Personnel), CNPq (National Council for Scientific and Technological Development) and FAPEMAT (Research Support Foundation of the State of Mato Grosso).

\section{References}

Alves MJF, Teixeira WWR, Daros E, Cassol LC, Pascoalino JAL, Moraes MF (2015) Productive performance of wheat based on nitrogen fertilization in coverage. Amer J Plant Sci. 6:1587-1593.

Brar MS, Singh B, Bansal SK, Srinivasarao C (2011) Role of potassium nutrition in nitrogen use efficiency in cereals. Res Findings. 29:20-27.

Bredemeier C, Mundstock CM (2001) Estádios fenológicos do trigo para a adubação nitrogenada em cobertura. Rev Bras Ciênc Solo. 25:317-323.

Carvalho JMG, Bonfim-Silva EM, Silva TJA, Sousa HHF, Guimarães SL, Pacheco AB (2016) Nitrogen and potassium in production, nutrition and water use efficiency in wheat plants. Ciênc Investig Agraria 43:442-451.

Chuan L, He P, Pampolino MF, Johnston AM, Jin J, XU X, Zhao S, Qiu S, Zhou W (2013) Establishing a scientific basis for fertilizer recommendations for wheat yield response and agronomic efficiency. Field Crops Res. 140:1-8.

Duan Y, Xu M, Gao S, Yang X, Huang S, Liu H, Wang B (2014) Nitrogen use efficiency in a wheat-corn cropping system from 15 years of manure and fertilizer applications. Field Crops Res. 157:47-56.

Fernandes MS (2006) Nutrição mineral de plantas. 1st edn. Sociedade Brasileira de Ciência solo, Viçosa. 432.

Flumignan DL, Lena BP, Faria RT, Scholz MBS, Medina CC (2013) Influence of irrigation on wheat crop. Eng Agríc. 33:75-88.
Gargantini H, Blanco HG, Haag HL, Malavolta E (1973) Absorção de nutrientes pelo trigo. Bragantia. 32:285-307.

Hejcman M, Kunzová E, Srek P (2012) Sustainability of winter wheat production over 50 years of crop rotation and $\mathrm{N}, \mathrm{P}$ and $\mathrm{K}$ fertilizer application on Illimerized Luvisol in the Czech Republic. Field Crops Res. 139:30-38.

IBGE. 2016. Sistema IBGE de Recuperação automática SIDRA. $2014 . \quad$ Available: http://www.sidra.ibge.gov.br/bda/tabela/listabl.asp?z=t\& $o=10 \& i=P \& c=1612$. Accessed Oct 15, 2016.

Lopes AS, Guilherme LAGA (2016) Career Perspective on Soil Management in the Cerrado region of Brazil. Adv Agron. 137:1-72.

Mendes WC, Alves Júnior J, Da Cunha PCR, Da Silva AR, Evangelista AWP, Casaroli D (2016) Potassium leaching in different soils as a function of irrigation depths. Rev Bras Eng Agríc Amb. 20:972-977.

Mojid MA, Wyseure GCL, Biswas SK (2012) Requirement of nitrogen, phosphorus and potassium fertilizers for wheat cultivation under irrigation by municipal wastewater. J Soil Sci Plant Nut. 12:655-665.

Niu J, Zhang W, Ru S, Chen X, Xiao K, Zhang X, Assaraf M, Imas $P$, Magen $H$, Zhang $F$ (2013) Effects of potassium fertilization on winter wheat under different production practices in the North China Plain. Field Crops Res. 140:6976.

Pietro-Souza W, Bonfim-Silva EM, Schlichting AF, Silva MC (2013) Desenvolvimento inicial de trigo sob doses de nitrogênio em Latossolo Vermelho de Cerrado. Rev Bras Eng Agríc Amb. 17:575-580.

Rosolem CA, Vicentini JPTMM, Steiner F (2012) Suprimento de potássio em função da adubação potássica residual em um Latossolo vermelho do Cerrado Rev Bras Ciênc Solo. 36:1507-1515.

SAS Institute (2002) SAS User's guide: statistics. 9th edn. CARY. 943.

Singh VK, Dwivedi BS, Tiwari KN, Majumdar K, Rani M, Singh SK, Timsina J (2014) Optimizing nutrient management strategies for rice-wheat system in the Indo-Gangetic Plains of India and adjacent region for higher productivity, nutrient use efficiency and profits. Field Crops Res. 164:3044.

Só e Silva M, Albrecht JC, Caierao E, Scheeren PL, Sobrinho JS, Trindade MG, Yamanaka $\mathrm{CH}$, Fronza V, Junior WQR, Nascimento Junior A (2008) BRS 254 - Wheat cultivar for irrigated conditions. Crop Breeding Appl Biotech. 8:96-98.

Theago EQ, Buzetti S, Teixeira Filho MCM, Andreotti M, Megda MM, Benett CGS (2014) Doses, fontes e épocas de aplicação de nitrogênio influenciando teores de clorofila e produtividade do trigo. Rev Bras Ciênc Solo. 38:1826-1835.

Yan W, Zhong Y, Shangguan Z (2015) The relationships and sensibility of wheat $\mathrm{C}: \mathrm{N}: \mathrm{P}$ stoichiometry and water use efficiency under nitrogen fertilization. Plant Soil Environ. 61:201-207.

Zhan A, Zoua C, Ye Y, Liu Z, Cui Z, Chen X (2016) Estimating on-farm wheat yield response to potassium and potassium uptake requirement in China. Field Crops Res. 191:13-19.

Zhang HM, Yang XY, He XH, Xu MG, Huang SM, Liu H, Wang $B R$ (2011) Effect of long-term potassium fertilization on crop yield and potassium efficiency and balance under wheat-maize rotation in China. Pedosphere. 21:154-163. 